\title{
Assessing the Nutritional Status and Blood Glutathione Level for Preschool Children.
}

\author{
Hanaa H. Elsayed * and Amr Abd El-Hafez** \\ *Chemistry of Nutrition and Metabolism Department, National Nutrition Institute. \\ ** Hotel Department Higher Institute for Tourism \& Hotel in $6^{\text {th }}$ October City.
}

\begin{abstract}
This study was designed to assessment nutrition status and blood glutathione (GSH) level for preschool children. Subjects and methods: The study included 70 (boys and girls preschool children) at aged from 2-5 years. Children was randomly selected from the out patients clinic at the National Nutrition Institute Cairo. Weigh and height were measured for them to evaluate the effect of nutrients on bodies, dietary intake was collected for the children were subjected to estimation of (Energy, Protein, Fat, Carbohydrate, vitamins A, folic acid and minerals iron, zinc and selenium) in their daily diet. Blood samples were collected to determine hemoglobin, glutathione and total protein concentration. Results: The dietary analysis showed that, every nutrient was lower than the requirement except total protein was higher than the recommend. Stunting showed $(25.5 \%)$ of boys and $(20 \%)$ of girls, underweight $(23 \%)$ of boys and $14 \%$ of girls were the problems among preschool children. A glutathione deficiency was found among $97 \%$ of boys and $100 \%$ of girls. The hemoglobin ratio $77.1 \%$ from children was equal or less than normal concentration. Total protein noticed $82.9 \%$ of boys and 85.7 of girls in normal value. Conclusion: There was little quantity of nutrients intake, glutathione level and growth. The study can be recommended to improve their daily dietary intake and nutrition habits by education programs for their parents or supplement of studied cases with special ferrous and protein specially contains sulphur amino acids in daily diet to cover Recommended Dietary Allowances and can improve tissue GSH concentration.
\end{abstract}

Key wards: Preschool Children -Glutathione - dietary intake - growth.

\section{Introduction}

Nutritional status is a major determinant of child health, and it is important to follow its evaluation over time not only for individual children but also at the community level. The classical use of anthropometry as the most readily available method of assessing nutritional status is logical although other methods (Briend et al., 1987). Nutritional deficiencies may give rise to a relative failure to grow in height (stunting) as well as a reduction in body mass for height (wasting). The latter is the condition dangerous to life in famines, but it responds much better in the short term to increased intake of nutrients than does the shortness of stature (David \&. Peter1998). In developing countries growth deficits are caused by two preventable factors, inadequate food and infection. In general, infections influence body size and growth through their effect on metabolism and nutrition (Torun and Viteri, 1981).

Growth can be defined as: "The progressive development of a living being or any of its parts from its earliest stage to maturity, including the attendant increases in size". Similarly, the definition of "development" is "The series of changes by which the individual embryo becomes a mature organism".

Clearly, a range of controls must influence the growth of a child. Genetic factors are important, as tall families have tall children and short families tend to have small children. Nutrition and environment are important contributors to the picture, as the child dose not growth well if it is starved or denied a good balanced diet or 
brought up in poverty. Finally, intrinsic factors such as hormones play a major part in starting the body to grow at the correct rate and appropriate time during childhood (David \&. Peter1998).

The reduced glutathione molecule consists of three amino acids - glutamic acid, cysteine, and glycine - covalently joined end-to-end. The sulfhydryl (-SH) group, which gives the molecule its electron-donating character, comes from the cysteine residue. Glutathione is present inside cells mainly in its reduced (electronrich, antioxidant) GSH form. In the healthy cell GSSG, the oxidized (electron-poor) form, rarely exceeds 10 percent of total cell glutathione. Intracellular GSH status appears to be a sensitive indicator of the cell's overall health, and of its ability to resist toxic challenge (Slater et al., 1995 and Duke et al., 1996).<smiles>NI(CCC(=O)NC(CS)C(=O)NCC(=O)O)C(=O)O</smiles>

Glutathione

Glutathione is present in the diet in amounts usually less than 100 milligrams daily and it does not appear that much of the oral intake is absorbed from the intestine into the blood. Glutathione is not an essential nutrient since it can be synthesized from the amino acids L-cysteine, L-glutamate and glycine. The liver is the principal site of glutathione synthesis. In healthy tissue, more than $90 \%$ of the total glutathione pool is in the reduced form and less than 10\% exists in the disulfide form. The enzyme glutathione disulfide reductase is the principal enzyme that maintains glutathione in its reduced form. This latter enzyme uses as its cofactor NADPH (reduced nicotinamide adenine dinucleotide phosphate). NADPH is gener-ated by the oxidative reaction in the pentose phosphate pathway (Strużńka et al., 2005). The changes in sulfhydryl status of the red blood cells are likely to play a major role for the erythrocytes (Anita and Chris 1997).

Glutathione's - $\mathrm{SH}$ character and its reducing power also set the redox stage for the proteins known as metallothioneins, which are able to bind with heavy metals and other potential sulfhydryl poisons to facilitate their subsequent removal from the body (Hidalgo et al.,1990). Metallothioneins are inducible, and their levels are augmented in response to heavy metal overload or related oxidative challenge. Human hereditary GSH deficiency states are not necessarily lethal, probably because some GSH is obtained directly from the diet (Klaasen and Lehman-McKeeman 1989).

Vitamins A (retinol), E (tocopherol) and $\mathrm{C}$ (ascorbic acid), glutathione (GSH) and selenium are first- line defences against oxidative stress and free radicals in biological systems (Singhal et al., 2001). Oral supplementation with vitamins $\mathrm{E}$ and $\mathrm{C}$, either alone or in combination, enhanced GSH level (Zaidi et al., 2005).

This study was designed to assessment nutrition status and blood glutathione (GSH) level for preschool children.

\section{Subject and Methods}

Seventy boys and girls preschool children aged from 2-5 years. They were randomly selected from the out patients clinic at the National Nutrition Institute Cairo, Egypt, during the period from January 2005 to March 2005. These children were subjected for the following:

1- Anthropometric measurements namely weight and height percentage / age to indicator to nutritional status. A normal range was according to (Recommended Dietary Allowances WHO/ FAO, 1989). The subject was weighted by standing bare footed on the center of the platform without touching or leaning on anything and with clothing worn and determined and according correction were done (WHO, 1995). The subject was placed bare footed underneath the measuring arm, feet 
parallel and with heels, shoulders and back of head touching the wall. The measuring arm was brought down on to the subject's head with the back plate firmly against the wall. The red cursor line was giving the accurate height measurement (WHO), 1995).

Duplicate observers for both weight and height were used.

2- Daily food and beverages with grams consumed by each child during the previous day to the interview were recorded; using dietary 24 hours recall methods (Gibson 1990). The analyses of macro and micro- nutrients were done using the food composition tables of National Nutrition Institute (1993). The nutritive value was compared with the recommended dietary allowances, WHO/ FAO, 1989 for the same sex and age.

3- Blood Samples were taken from vein of children and preserved in heparinzed tubes. Part of the sample was taken immediately for hemoglobin and glutathione determination according to (Varly et al., 1980 and Beutler et al., 1963) method. A cut-off point of less than $12 \mathrm{~g} / \mathrm{dl}$ was considered to indicate hemoglobin deficiency (WHO, 1972) and Beutler et al. (1963) criteria were used to determine the cut-off point for glutathione. The second part of blood rest at room temperature for $15 \mathrm{~min}$. and then centrifuged at 4000 r.p.m for 15 min. Plasma level of total protein was determined and cut-off point according to (Domas, 1975).

\section{Statistical analysis:}

For the purpose of statistical comparison anthropometric indices were expressed as height and weight for age $\mathrm{z}$ scores (HAZ) (WHO, 1983). Z score was calculated for height and weight for age using computer program ANTHRO \{version 1.01 1990\}. The collected data were processed using the software SPSS (Statistical Package for Social Science, version 10), 2002.

\section{Results}

The growing child can be adversely affected by diet, social environment or poisons in the atmosphere. Thus the environment (a child grows up in) can have a marked effect on its physical development. Environmental pollution from chemicals is also known to affect individuals and their growth and clearly poses a risk to the unborn child. Pesticides and agricultural fertilizers are also widely dispersed in the environment and can find their way into the food chain, with impacts on health found retrospectively (David \& Peter, 1998). GSH may be especially important for those organs most directly exposed to exogenous toxins, such as lungs, intestines, kidneys, and particularly liver (Strużńka et al., 2005).

Malnourished children exhibit delayed growth. Body proportions at birth such as weight related to length are also a good indicator of a time of restraint of growth during pregnancy. After a period of human malnutrition has ended, growth accelerates in an attempt to compensate for the loss in height and weight (David \& Peter1998).

\section{1-The nutritional data:}

Table (1) represented the mean \pm SD of nutrient intake with RDA. It can be noticed that energy was $58.8 \%$ and $61.1 \%$ RDA of boys and girls respectively. Fat was $18.6 \%$ of energy RDA mean of grand Vs $30 \%$ of energy RDA. Carbohydrate intake was decreased in all children Vs energy RDA. Statically differences between boys and girls in percentage of dietary intake in all status were no significant between of them. Total protein intake was increased than RDA in all subjects but the intake in boys was increased than girls by range. Data in table (2) have shown that multiple micronutrient deficiencies. Zinc was severing deficiency (19\% and 17\% RDA of boys and girls). Selenium, Vitamin $A$ and folic acid have showed deficiency, they were nearest to 50\% RDA of all gender. 


\section{2- Anthropometric measurements:}

The age, weight and height of the children at each gender are shown in table (3). At age range were $2-5$, year. There were no between- gender remark differences in age, weight and length for age. The boys were slightly increased, in all anthropometric measurements compared with girls' kinds. Regarding to weight and height showed high normal weight and height percentage for girls. The underweight and stunting percentage increased for boys. Stunting showed $(25.5 \%)$ of boys and $(20 \%)$ of girls, underweight $(23 \%)$ of boys and $14 \%$ of girls were the problems among preschool children.

\section{3-Biochemical analysis}

Biochemical analysis was summarized in table (4). Hemoglobin level in blood was decreased than normal, beside to statistically in hemoglobin level differences between boys and girls. The decreasing and equal ratio estimated to be
$77.1 \%$ for both geniuses comparing with the normal value.

Glutathione binding capacity state is normal as total $47-59 \mathrm{mg} / \mathrm{dl}$ with average $53 \pm 6.0 \mathrm{mg} / \mathrm{dl}$. GSH value in blood was decreased in all geniuses than mean normal value. There were statistical differences between boys and girls, where the recorded number of mean value $<47 \leq 59$ for $\mathrm{GSH}$ was one for boys set-off zero for girls.

The maximum reduction in GSH level was $25.5 \pm 8.5 \mathrm{mg} / \mathrm{dl}$ to girls' genus opposite $27.2 \pm 8.1 \mathrm{mg} / \mathrm{dl}$ to boys' genus compared with normal level 47-59 $\mathrm{mg} / \mathrm{dl}$, may be children exposed to pollutants or the content of micro- nutrients which contain glutathione no efficient in their food intake.

Total protein state is normal in both examined kinds, ranging from $7.3 \pm 0.93$ $\mathrm{g} / \mathrm{dl}$ Vs $7.8 \pm 1.2$ for boys and girls in all children except, $17.1 \%$ Vs $14.3 \%$ for boys and girls respectively were decreased than mean normal value $6.5 \mathrm{~g} / \mathrm{dl}$.

Table (1): Mean daily intake of macro-nutrients for Preschool Children \pm SD.

\begin{tabular}{|c|c|c|c|c|c|c|}
\hline \multicolumn{2}{|l|}{ Parameter } & RDA & Boys & Girls & $\begin{array}{l}\text { Mean of } \\
\text { gender } \\
\mathrm{n}=70\end{array}$ & Sig. \\
\hline \multirow[b]{2}{*}{ Energy } & $\begin{array}{l}\text { Mean } \\
\text { (K.call)/day }\end{array}$ & 1550 & $912.1 \pm 320$ & $947.6 \pm 383$ & 929.8 & N.S \\
\hline & \% \% of RDA & 100 & 58.8 & 61.1 & 60.0 & \\
\hline \multirow[b]{2}{*}{ Total protein } & Mean (g)/day & 28.5 & $32.3 \pm 3.14$ & $30.4 \pm 3.16$ & $31.4 \pm 3.15$ & N.S \\
\hline & $\begin{array}{l}\% \text { of energy } \\
\text { RDA }\end{array}$ & $15 \%$ & 8.33 & 7.85 & 8.1 & \\
\hline Animal protein & Mean $(\mathrm{g})$ & & $14.9 \pm 3.1$ & $13.8 \pm 5.1$ & $14.4 \pm 4.1$ & N.S \\
\hline \multirow{2}{*}{ Total fat } & $\begin{array}{l}\begin{array}{l}\text { Mean of fat } \\
(\mathrm{g}) / \text { day }\end{array} \\
\end{array}$ & & $31.3 \pm 1.4$ & $33.1 \pm 1.6$ & $32.0 \pm 1.5$ & N.S \\
\hline & $\begin{array}{ll}\% \text { of } & \text { energy } \\
\text { RDA } & \\
\end{array}$ & $30 \%$ & 18.2 & 19.2 & 18.6 & \\
\hline Animal fat & Mean $(\mathrm{g})$ & & $14.5 \pm 1.2$ & $14.4 \pm 1.2$ & $14.5 \pm 1.2$ & N.S \\
\hline \multirow{2}{*}{ Carbohydrate } & Mean $(\mathrm{g})$ & & $120.1 \pm 45.9$ & $122.6 \pm 46.8$ & $121.3 \pm 46.1$ & N.S \\
\hline & $\begin{array}{l}\% \text { of } \\
\text { RDA }\end{array}$ & $55 \%$ & 31.0 & 31.6 & 31.3 & \\
\hline
\end{tabular}

$($ N.S $)=$ Non Significant 
Table (2): Mean daily intake of micro-nutrients for Preschool Children \pm SD.

\begin{tabular}{|c|c|c|c|c|c|c|}
\hline \multicolumn{2}{|l|}{ Parameter } & RDA & Boys & Girls & $\begin{array}{l}\text { Mean of } \\
\text { gender } \\
n=70\end{array}$ & Sig. \\
\hline \multirow[b]{2}{*}{ Total Iron } & Mean iron (mg) & 10 & $6.5 \pm 0.7$ & $7.5 \pm 0.6$ & $7.0 \pm 0.65$ & N.S \\
\hline & $\%$ of RDA & 100 & 65 & 75 & 70 & \\
\hline $\begin{array}{l}\text { Animal } \\
\text { iron }\end{array}$ & $\begin{array}{ll}\text { Mean animal } \\
\text { iron }(\mathrm{g})\end{array}$ & & $2.3 \pm 0.4$ & $2.7 \pm 0.4$ & $2.5 \pm 0.3$ & N.S \\
\hline \multirow{2}{*}{ Zinc } & $\begin{array}{l}\begin{array}{l}\text { Mean of zinc } \\
(\mathrm{g})\end{array} \\
\end{array}$ & 10 & $1.9 \pm 1.1$ & $1.7 \pm 0.87$ & $1.8 \pm 0.8$ & N.S \\
\hline & \% of RDA & 100 & 19 & 17 & 18 & \\
\hline \multirow{2}{*}{ Selenium } & $\begin{array}{l}\text { Mean of } \\
\text { Selenium }(\mu g)\end{array}$ & 20 & $10.4 \pm 4.7$ & $9.8 \pm 5.3$ & $10.1 \pm 0.4$ & N.S \\
\hline & $\%$ of RDA & 100 & 52 & 49 & 50.5 & \\
\hline \multirow{2}{*}{ Vitamin A } & $\begin{array}{l}\text { Mean of } \\
\text { vitamin } A \mu g\end{array}$ & 500 & $259.3 \pm 30$ & $219.6 \pm 21$ & $239.5 \pm 25$ & N.S \\
\hline & \% of RDA & 100 & 52 & 44 & 48 & \\
\hline \multirow{2}{*}{ Folic acid } & $\begin{array}{l}\text { Mean of folic } \\
\text { acid } \mu \mathrm{g}\end{array}$ & 63 & $24.1 \pm 0.4$ & $36.6 \pm 0.5$ & $30.4 \pm 0.4$ & N.S \\
\hline & $\%$ of RDA & 100 & 38.3 & 58.1 & 48.3 & \\
\hline
\end{tabular}

(N.S) $=$ Non Significant

Table (3): Percent Distribution of Weight and Height /Age for Preschool Children \pm S.D.

\begin{tabular}{|c|c|c|c|c|c|}
\hline \multicolumn{2}{|l|}{ Characterizes } & \multirow{2}{*}{$\begin{array}{l}\text { Rang } \\
2-5 \text { year }\end{array}$} & \multirow{2}{*}{$\begin{array}{l}\text { boys } \\
3.8 \pm .01\end{array}$} & \multirow{2}{*}{$\begin{array}{l}\text { Girls } \\
3.8 \pm 0.02\end{array}$} & \multirow{2}{*}{$\begin{array}{l}\text { Sig. } \\
\text { N.S }\end{array}$} \\
\hline Age & & & & & \\
\hline & Mean \pm S.D. & $16.5 \mathrm{Kg}$ & $14.6 \pm 3.4$ & $14.5 \pm 2.5$ & N.S \\
\hline Weight/age & $\begin{array}{l}\text { Underweight } \\
\text { Normal } \\
\text { overweight }\end{array}$ & $\begin{array}{l}<-2 \text { S.D. } \\
-2 \text { to }+2 \text { S.D. > } \\
+2 \text { S.D. }\end{array}$ & $\begin{array}{rr}\text { No } & \% \\
8 & 23.0 \\
26 & 74.0 \\
1 & 3.0\end{array}$ & $\begin{array}{rr}\text { No } & \% \\
5 & 14.0 \\
30 & 86.0 \\
0 & 0.0\end{array}$ & \\
\hline & Mean \pm S.D. & $101 \mathrm{~cm}$ & $100.2 \pm 10.1$ & $96.9 \pm 7.6$ & N.S \\
\hline Height/age & $\begin{array}{l}\text { Stunting } \\
\text { Normal } \\
\text { Tall }\end{array}$ & $\begin{array}{ll}<-2 & \text { S.D. } \\
-2 \text { to } & +2 \text { S.D. } \\
>+2 & \text { S.D. }\end{array}$ & $\begin{array}{rr}\text { No } & \% \\
9 & 25.5 \\
24 & 68.5 \\
2 & 6.0 \\
\end{array}$ & $\begin{array}{rc}\text { No } & \% \\
7 & 20.0 \\
27 & 77.0 \\
1 & 3.0 \\
\end{array}$ & \\
\hline Total number & & & 35 & 35 & 35 \\
\hline
\end{tabular}

$($ N.S) $=$ Non Significant 
Table (4): Mean Glutathione, Hemoglobin and Total Protein for Preschool Children \pm S.D.

\begin{tabular}{|c|c|c|c|c|c|}
\hline Parameter & $\begin{array}{ll}\text { Cut } \\
\text { Point }\end{array}$ & & Boys & Girls & $\overline{\mathbf{P}}$ \\
\hline \multirow{2}{*}{$\begin{array}{l}\text { Hemoglobin } \\
\text { g/dl }\end{array}$} & \multirow[t]{2}{*}{$>12$} & "Mean & $11.2 \pm 1.2$ & $10.9 \pm 1.5$ & I N.S \\
\hline & & $\begin{array}{l}\geq 12 \\
<12\end{array}$ & $\begin{array}{lc}\text { No } & \% \\
27 & 77.1 \\
8 & 22.9\end{array}$ & $\begin{array}{lc}\text { No } & \% \\
27 & 77.1 \\
8 & 22.9\end{array}$ & \\
\hline \multirow{2}{*}{$\begin{array}{l}\text { Glutathione } \\
\text { (GSH)mg/dl }\end{array}$} & $47-59$ & Mean & $27.2 \pm 8.1$ & $25.5 \pm 8.5$ & N.S \\
\hline & & $\begin{array}{l}\geq 47 \\
<47 \leq 59\end{array}$ & $\begin{array}{ll}\mathrm{No} & \% \\
34 & 97.0 \\
1 & 3.0\end{array}$ & \begin{tabular}{lr} 
No & \multicolumn{1}{c}{$\%$} \\
35 & 100.0 \\
0 & 0.0
\end{tabular} & \\
\hline \multirow[t]{2}{*}{ T. Protein } & $6.5-8.5$ & Mean & $7.3 \pm 0.96$ & $7.8 \pm 1.2$ & N.S \\
\hline & & \multirow[t]{2}{*}{$\begin{array}{l}\geq 6.5 \\
<6.5 \leq 8.5\end{array}$} & $\begin{array}{ll}\text { No } & \% \\
6 & 17.1 \\
29 & 82.9 \\
\end{array}$ & $\begin{array}{lc}\text { No } & \% \\
5 & 14.3 \\
30 & 85.7 \\
\end{array}$ & \\
\hline Total number & & & 35 & 35 & 35 \\
\hline
\end{tabular}

$(\mathrm{N} . \mathrm{S})=$ Non Significant

\section{Discussion}

\section{1-The nutritional data;}

Energy is important for children, as it affects their activity and growth, it was noticed that dietary energy intake $58.8 \%$ RDA of male, that agree with results obtained El- Bahay et al., (2004). Zinc, selenium, iron or vitamin A deficiency may cause linear growth retardation (Kolsten, 1996). Zinc ions can bind with sulphydryl group in proteins, thus protecting them against oxidation (Bender and Bender 1997). Zinc and selenium are required for the formation of enzymes (superoxide dismutase, catalase and glutathione peroxidase) that remove reactive oxygen species, and so provide protection (Bender, 1997). Total iron intake was lower than the genus need (Gibson, 1990), this lead to consume more iron as oxidant agent (Paige, 1988). All children had equal or nearest $50 \%$ of RDA from vitamin A, these results agreed with that reported by Abd El Fatah, (2002) who found that all children had vitamin A intake deficiency at all age groups. Vitamin A inadequacy is most probably due to the fact that most food sources of vitamin A are from plant origins which are characterized by low bioavailability. Vitamin A supplementation is an accepted policy to reduce infant mortality in developing countries, as a first step toward food based strategies to combat vitamin A deficiency (Moussa, 2000). Vitamin A deficiency and iron deficiency anemia as well as growth retardation ACC/SCN, (1997). On the other hand there are many agents that can destroy this unstable elements and vitamin like heat, oxygen, alkalis and water for example food which is refrigerated, uncovered and exposed to air or microwave lead to destroy of these elements (Tolenen, 1990). Children consume large amount of dairy product which is very low in iron (Mahan, 1996).

\section{2- Anthropometric measurements:}

The measure of growth and body composition in the child is the most objective indicator of that child's nutritional status (Baer et al., 1990). The results percentage of stunting was agreed with Abd El-Maksoud et al. (1997) found that stunted preschool children less than 3 years of age represented $22.9 \%$. The weight is probably appropriate for their length in all groups. These results agree with NCHS, 
(1981). Growth retardation is one of the most common nutritional problems in the world. In Egypt it was estimated that 19\% of the Egyptian children are stunted due to poor nutrition, (UNICEF, 2003).

\section{3-Biochemical analysis:}

The obtained results clear the relation between hemoglobin level and total protein (conjugated protein) table (4). Hemoglobin level in blood was decreased than normal, in agreement with that of Abd El-Ghany and Shaheen (2000). Hemoglobin is oxygen carrying pigment in red blood cell (RBC), a conjugated protein contain 4 heme groups combined with iron and 4 long poly peptide chains forming the protein globulin, it made by developing RBC in bone narrow, caused reducing in hemoglobin ratio and kept the protein in normal level in all status. Hamburger and Weinsier (1997) showed that about $70 \%$ of iron in hemoglobin, $5 \%$ in myoglobin and pool bound to transferring (the iron transported protein) so hemoglobin is a good indicator for iron status.

The reduction of blood glutathione level obtained for boys and girls in this study (table 4). Theses results were agreed with Calvin et al., (2001) showed that, blood GSH is lower in children than in young adults. The GSH differences between boys and girls may be due to the amount of metabolite and not to the concentration expression as per milliliter of blood, per milliliter of plasma, or per $10^{10}$ red blood cell. These terms are based on red blood cell count and hemoglobin content (Long et al., 2001). On the other hand the GSH status drops found in various human and animal populations. This phenomenon may be due to suboptimal nutrition and unhealthy and stressful conditions (Kleinman and Richie, 2000). Stevens and Anders, (1981) reported that, the potential therapeutic use of GSH or its precursors for treatment of toxicity by depleted tissue GSH stores. Then decreased tissue GSH concentration is associated with the clinical onset of chemical toxicity.

Low-protein diets or diets deficient in sulphur amino acids can influence tissue GSH concentration, which decreased during consumption low-protein (Cho et al., 1984).
Nutritional status may influence tissue GSH concentration by affecting the uptake of extracellular GSH into extrahepatic tissues via $\gamma$-glutamyl traspeptidase and by affecting the transport of plasma amino acids into tissues, the influence of nutritional status on extrahepatic tissue GSH concentration (Taylor et al., 1992). The protective effect of cysteine on GSH depletion has been reported in many other culture models as well, including gastric cells, human retinal pigment epithelium and human endothelial cells (Hiraishi et al., 1994). Intravenous supply of cysteine to GSHdepleted rats caused marked increases in hepatic GSH in vivo (Aebi and Lauterberg, 1992). Using cysteine derivatives, other studies reinforce the hypothesis that cysteine availability is the critical ratelimiting step in GSH synthesis (Witschi et al., 1995). Although most evidence suggests that cysteine is the limiting amino acid for GSH synthesis, glutamine supplementation may be beneficial for maintaining tissue GSH in situation of high energy and nutrient demand such as sever trauma (Welbourne et al., 1993).

The data obtained from these investigations can be concluded that there was iron deficiency anemia due to error in selection of some nutrients such as higher plant source of protein than animal organ in diet accompanied with decrease sulphur amino acid protein intake.

The study can be recommended to improve the daily dietary intake by education programs for parents of children or supplement of studied cases with special ferrous and protein specially contains sulphur amino acids in daily diet to cover RDA and can improve tissue GSH concentration.

\section{References}

1. Abd El-Ghany $\mathbf{M} \mathbf{A}$ and Shaheen $\mathbf{K} \mathbf{A}$ (2000): Study the correlation between nutritional status and some blood biochemical values as indicator of anemia in school student. Egyptian Conference of Home Economics- Minufiya Univ. Faculty of Home Economics (16-17) July 2000.

2. Abd El- Fatah AE (2002): Evaluation of group feeding program in some institution 
in Cairo Governorate M.Sc. Thesis, Faculty of Home Economics, Menofia University, Egypt.

3. Abd El-Maksoud A M, Tawfik A.A and Moussa WA (1997): Anthropometric measurement and plasma retional level of preschool children in Egypt. Sci. Med. J. Escme, 9 (4) 1-10

4. ACC/SCN (1997): Third report on the world nutrition situation. A report compiled from information available to the ACC/ SCN, December.

5. Aebi S and Lauterburg B H (1992): Divergent effects of intravenous GSH and cysteine on renal and hepatic GSH. American Journal of Physiology, 263, 348-352.

6. Anita A M G and Chris T A (1997): Hydroxylamine Treatment Increases Glutathione- Protein and Protein-Protein Binding in Human Erythrocytes Copyright (c) by the Blood Cells Foundation, La Jolla, California USA, Academic Press SpringerVerlag, Inc.

7. Baer MT, Waldron J, Gumm H, Van Dyke DC and Chang H (1990): Nutrition assessment of the child with Down syndrome. In Clinical Perspectives in the Management of Down syndrome. SpringerVerlag, NY, 107-125

8. Bender A D (1997): Introduction to nutrition and metabolism, second edition, British library cataloguing in publication data, pp. 30-31.

9. Bender DA and Bender AE (1997): Nutrition a reference handbook publicizes by Oxford New York Melbourne Toronto, pp 424-426.

10. Beutler E, Duron $\mathbf{O}$ and Kelly B M (1963): The determination of blood glutathione, J. Lab, \& Clin. Med., 61: 882-888.

11. Briend A, Wojtyniak B and Rowlan M G M. (1987): Arm circumference and other factors in children at high risk of de-ath in rural Bangladesh. Lancet, 2:725-728.

12. Cho ES, Johnson $\mathbf{N}$ and Snider B C (1984): Tissue glutathione as a cysteine reservoir during cystine depletion in growing rats. Journal of Nutrition, 114: 1853-1862.

13. David S and Peter D (1998): Human growth after birth, sixth edition. Published in the United States by Oxford University press Inc., New York. P 1-3.

14. Domas B T (1975): The determination of sulfhydryl groups in serum, Clin. Chem., 21: 1159-1166.
15. Duke RC, Ojcius DM. and Young JD-E. (1996): Cell suicide in health and disease. Scientific American, 60: 79-87.

16. El-Bahay AM, El-Te'llawy F, Zakly M N. and Gad El Rab R (2004): study of the nutritional status of the abnormal teenagers at the Juvenile Correctional Institution at ElMinia Governorate. Bull Nat. Nutr. Inst. Cairo. Egypt., 26: 147-156.

17. Gibson RS (1990): Principles of nutritional assessment. Oxford university press, New York, Oxford.

18. Hidalgo J, Garvey JS and Armario A (1990): On the metallothionein, glutathione and cysteine relationship in rat liver. J Pharmacol Exptl Ther., 255:554-564.

19. Hiraishi H, Terano A, Ota S, Mutoh H, Sugimoto T., Varada T., Razandi M V and Ivey K J (1994): Protection of cultured rat gastric cells against oxidant- induced damage by exogenous glutathione. Gastroenterology., 106: 1199-1207.

20. Humburger DC and Weinsir R L (1997): Handbook of clinical nutrition $3^{\text {rd }}$ ed. St. Loves Mosby year book 1997.

21. Klaasen C D and Lehman-McKeeman LD (1989): Induction of metallothionein. J Am Coll Toxicol., 8:1315-1321.

22. Kleinman W and Richie JP (2000): Status of glutathione and other thiols and disulfides in human plasma. Biochem. Pharmacol., 60: 19-29.

23. Kolsten P (1996): The determination of stunting: Can we regard the linear growth performance as a continuation of fetal growth. Asia Pacific J Clin. Nutr., 5:59-69.

24. Long CA, Matheng A P, Mastropaolo J W and Liu M C (2001): Blood glutathione and cysteine concentrations in twin children. Society for Experimental Biology and Medicine. 226: 349-352.

25. Moussa AW (2000): Vitamin A status in Egypt, approach towards virtual elimination of vitamin A deficiency by the year 2000, National conference of Nutrition Situation of Micronutrients in Egypt. P 95.

26. National Center for Health Statistics (NCHS) (1981): Growth percentiles for children. A dopted jrow frisancho AR: New ariorins of upper limb jat and muscle areas for assessment of nutritional status. Am. J. Clin. Nutr., 34: 2540.

27. National Nutrition Institute (NNI) (1993): Food consumption pattern and nutrients intake among different population groups. Supported by WHO/ EMRO. 
28. Paige D M (1988): Clinical nutrition. Mosby Company Washington.

29. Recommended Dietary Allowances (RDA), FAO and WHO(1998): FAO, WHO, 1998, Joint FAO, WHO expert consultation on Human Vitamin and Mineral requirements, FAO, Bangkok, Thailand, September, 21-30.1998.

30. Taylor CG, Bauman P F, Sikorski B and Bray T M (1992): Elevation of lung glutathione by oral supplementation of 1-2oxothiazolidine-4-carboxylate protects against oxygen toxicity in protein energy malnourished rats. FASB., 6: 3101-3107.

31. Tolenen M (1990): vitamin and minerals in health and nutrition, west Sussex, England, Ellis Horwood limited.

32. Torun B and Viteri FE (1981): Energy requirements of preschool children and effect of varying intakes on protein metabolism. Food and nutrition Bulletin Suppl., 5: 229-241.

33. Singhal RK, Anderson ME and Meister A (2001): Glutathione, a first line of defense against cadmium toxicity, FASEB J., 1: 2203.

34. Slater AFG, Stefan C and Nobel I (1995): Signaling mechanisms and oxidative stress in apoptosis. Toxicol. Letts; 82/83:149-153.

35. SPSS (2002): statistical package for social science, computer software (version 10, USA).

36. Stevens $J$ L and Anders M W (1981): Effect of cysteine, diethyl maleate, and Phenobarbital treatments on the hepato- toxicity of $1(\mathrm{H})$ chloroform. ChemicoBiological Interactions., 37: 207-217.

37. Strużńka L, Chalimoniuk $M$ and Sulkowski G (2005). "The role of astroglia in $\mathrm{Pb}$-exposed adult rat brain with respect to glutamate toxicity". Toxicology., 212 (23): $185-194$

38. UNICEF (2003): "The state of world children" UNICEF New York.

39. Varly H,Gowenlook A $\mathbf{H}$ and Bell $\mathbf{H}$ (1980): "Determination of hemoglobin" in Practical Clinical Biochemistry; $5^{\text {th }}$ Ed., Vol.(1), William Heinemann, Medical Book LTD, London.

40. Welbourne TC,King A B and Horton K (1993): Glutathione supports hepatic glutathione efflux during inflammation. Journal of Nutrition Biochemistry., 4: 235242.

41. WHO (1972) : Nutritimal anemia, WHO ( Wurld health organizatian) Technical report series No.3, Geneva.

42. WHO (1983): Measuring change in nutritional status. Gaudiness for assessing the nutritional impact of supplementary feeding programmers, for vulnerable group. WHO. Geneva.

43. WHO (1995): Global Prevalence of Vitamin A deficiency. Micronutrient deficiency Information System MIDS working paper2.

44. Zaidi KSMR,Tariq M,Al-Qirim and Banu N (2005): Effects of antioxidant vitamins on glutathione depletion and lipid peroxidation induced by restraint stress in the rat liver. J. drug, (3):157-165. 


\section{"تقييم الحالة التظذية ومستوى جلوتاثيون الدم لأطفال سن ما قبل المدرسة "}

\section{هناء حسين السبد 1، عمرو عبد الحافظ محمد 2}

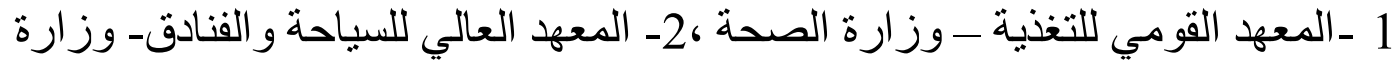

التعليم العالي

صمدت هذه الدر اسة لتقييم الحالة الغذائية و مستوى الجلوتاثيون في دم أطفال ماقبل

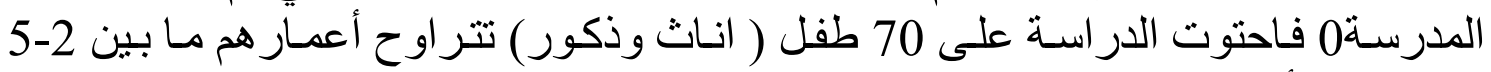

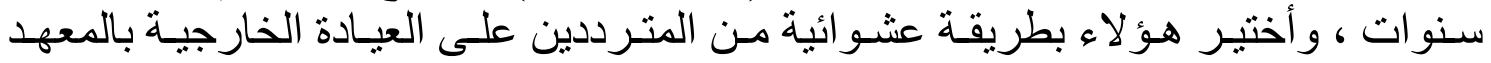

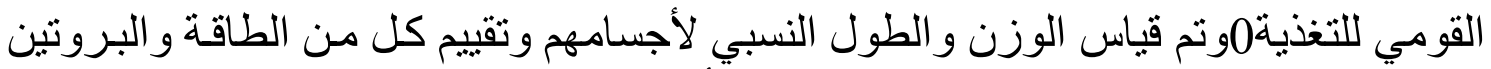

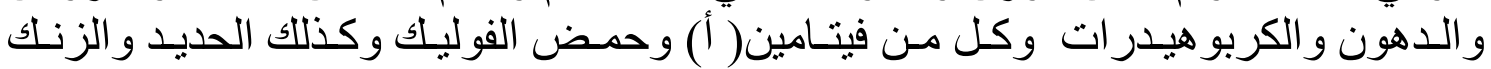

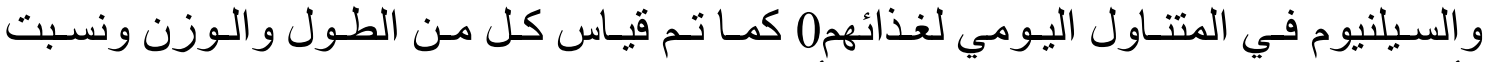

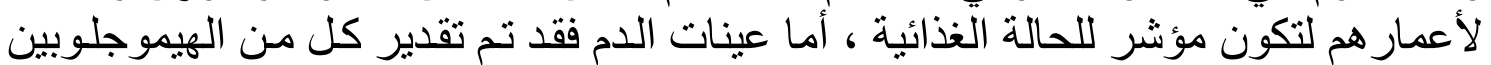

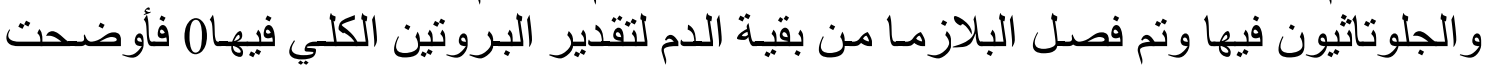

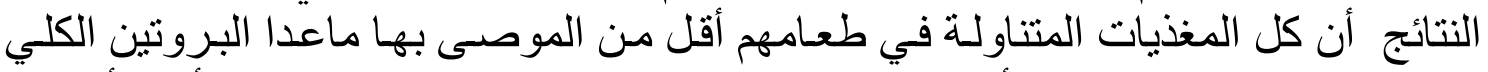

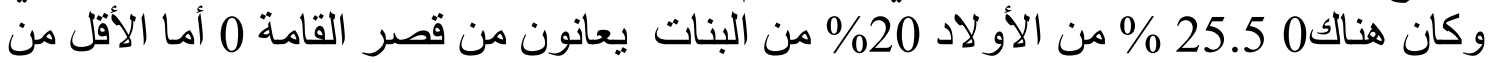

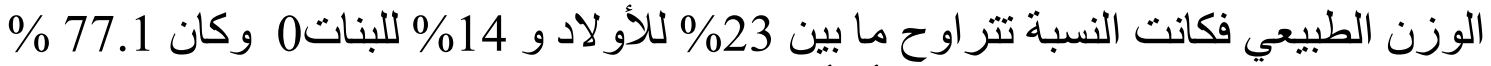

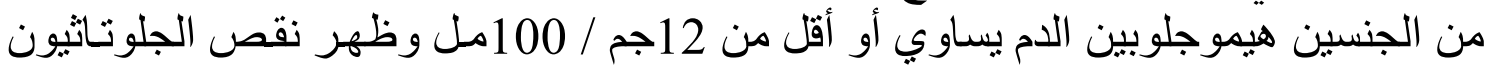

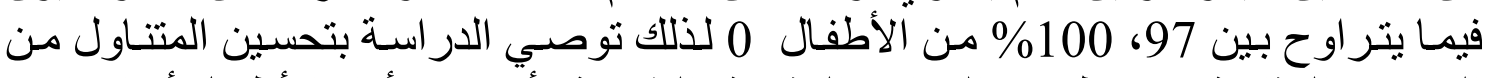

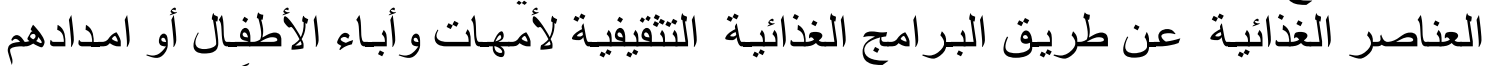

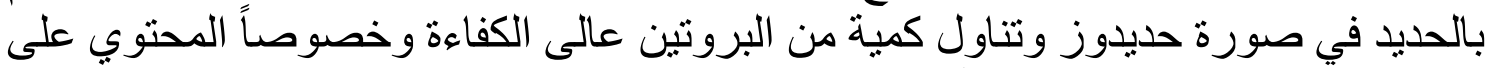

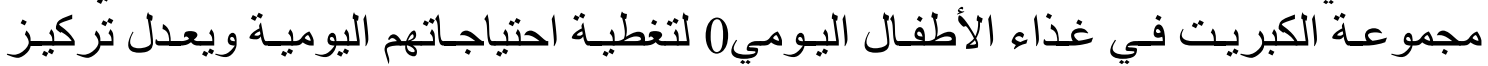
الجلوتاثيون في أجسامهر. 